Check for updates

Cite this: RSC Adv., 2019, 9, 29652

\title{
Synthesis of novel functional ionic liquids and their application in biomass
}

\author{
Hui-Ying Han, (D) a Xin Geng, ${ }^{a}$ Bi-Xian Zhang, ${ }^{c}$ Jing Meng, ${ }^{a}$ Xin Liu, ${ }^{a}$ Xin-Miao He, ${ }^{\text {bc }}$ \\ Zi-Guang Liu, bc Yun-Fei Gao, ${ }^{c}$ Di Liu ${ }^{* b c}$ and Xiao-Mei Hu*a \\ A series of dicationic ionic liquids (ILs) including [PF 6$]\left[(\mathrm{PYR}) \mathrm{C}_{4}(\mathrm{MIM})\right][\mathrm{Cl}]$, [PF 6 ][(PYR) $\left.\mathrm{C}_{4}(\mathrm{PYR})\right][\mathrm{Cl}]$, [PF 6 ][(PYR) \\ $\left.\mathrm{C}_{5}(\mathrm{MIM})\right]\left[\mathrm{Cl}\right.$, and $\left.\left[\mathrm{PF} \mathrm{F}_{6}\right](\mathrm{PYR}) \mathrm{C}_{5}(\mathrm{PYR})\right][\mathrm{Cl}]$, and monocationic ILs including [(PYR) $\mathrm{C}_{4} \mathrm{Cl}_{[}\left[\mathrm{PF} \mathrm{F}_{6}\right]$, [(PYR) $\mathrm{C}_{5} \mathrm{ClJ}\left[\mathrm{PF}_{6}\right]$, \\ $\left[(\mathrm{MIM}) \mathrm{C}_{2} \mathrm{COOH}\right]\left[\mathrm{PF}_{6}\right]$ and $\left[(\mathrm{PYR}) \mathrm{C}_{2} \mathrm{COOH}\right]\left[\mathrm{PF}_{6}\right]$ were synthesized. Their thermal stability and melting points \\ were determined. Their solubility with organic solvents and the miscibility with water were investigated. \\ These functional ILs are hydrophilic at high temperatures and they are hydrophobic at low temperatures, \\ which enable the effective isolation of the resulting reducing sugar. High yields of reducing sugar were \\ obtained for corn stalk after $8 \mathrm{~h}(20.73 \%)$ and potato starch after $6 \mathrm{~h}(72.50 \%)$ by the treatment with the \\ mixture of $\left[\mathrm{PF}_{6}\right]\left[(\mathrm{PYR}) \mathrm{C}_{4}(\mathrm{PYR})\right][\mathrm{Cl}]$ and $\left[(\mathrm{PYR}) \mathrm{C}_{2} \mathrm{COOH}\right]\left[\mathrm{PF}_{6}\right]$. The reuse of dicationic and monocationic ILs \\ was successfully performed and no significant reduction in yields of reducing sugar was observed. These \\ functional ILs have important implications in the design of homogeneous and heterogeneous systems \\ with water and organic solvents, which could be used to satisfy some specific applications.
}

Received 10th August 2019

DOI: $10.1039 / c 9 r a 06243 b$

rsc.li/rsc-advances

solvents followed by the enzymatic hydrolysis, are widely utilized in academic and industrial applications. ${ }^{21-25}$ The pretreatment of cotton stalk was performed at $150{ }^{\circ} \mathrm{C}$ for $30 \mathrm{~min}$ in 1-ethyl-3-imidazolium acetate ([EMIM] $\mathrm{CH}_{3} \mathrm{COO}$ ) to release $65 \%$ of reducing sugars after $72 \mathrm{~h}$ of enzymatic hydrolysis. ${ }^{26}$ The saccharication degree of [EMIM] $\mathrm{CH}_{3} \mathrm{COO}$-pretreated corn stalk by the crude enzyme of Penicillium oxalicum HC6 and the cellulase from Trichoderma reesei ATCC26921 were determined as $24.58 \%$ and $21.40 \%$, respectively. ${ }^{27}$

Currently, functional acidic ILs as catalysts and solvents become potentially a sustainable approach, which avoid the addition of mineral acid in the hydrolysis process of lignocelluloses. As reported, hydrolysis of fiber sludge using hydroxyalkylimidazolium hydrogen sulphate produced $29 \%$ of reducing sugars at $100{ }^{\circ} \mathrm{C}$ for $30 \mathrm{~min} .{ }^{28}$ Hydrolysis of switchgrass in 1-(sulfobutyl)-3-methylimidazolium chloride resulted in $58.1 \%$ reducing sugars under thermal and microwave conditions for the pretreatment for $1 \mathrm{~h}$ at $70{ }^{\circ} \mathrm{C}$ followed by treatment with the addition of water for another $1 \mathrm{~h}$ at $70{ }^{\circ} \mathrm{C}^{29}$

Although ILs-pretreatments of lignocelluloses are successfully utilized, the low rate and high cost of cellulase limit their industrial utilization. The addition of a large amount of corrosive inorganic acid may cause environmental problems. Actually, all the ILs for lignocellulose treatment are hydrophilic in current studies, thus it is much difficult to separate reducing sugar from the common ILs and also functional acidic ILs. The recovery and reuse of hydrophilic ILs become a problem. ${ }^{\mathbf{3 0}, 31}$ The alternative techniques are still necessary to achieve the sugars in the conversion of biomass to biofuels.
${ }^{a}$ College of Life Sciences, Northeast Agricultural University, Harbin, 150030, China. E-mail: huxiaomei1982@163.com

${ }^{b}$ Key Laboratory of Combining Farming and Animal Husbandry, Ministry of Agricultural and Rural Affairs, Harbin, 150086, China.E-mail: liudi1963@163.com ${ }^{c}$ Heilongjiang Academy of Agricultural Sciences, Harbin, 150086, China 
In this study, a series of novel functional ionic liquids were synthesized. These ILs are hydrophilic at high temperatures and they are hydrophobic at low temperatures, which provide an opportunity to improve the isolation of sugars and the reuse of ILs. Both dicationic ILs and monocationic ILs were investigated for their physicochemical properties including thermal stability, the melting points, the solubility in water and organic solvents. The ILs were investigated for the first time in the conversion of potato starch and corn stalk to prepare reducing sugar.

\section{Results and discussion}

\section{Synthesis of ionic liquids}

Ionic liquids were synthesized using quaternization reaction followed by anion metathesis. The synthetic route for dicationic ionic liquids (DILs) was shown in Scheme 1. Initially, [(PYR) $\mathrm{CnCl}]\left[\mathrm{PF}_{6}\right]$ was prepared by heating one equivalent of pyridine with one equivalent of dichloroalkane in solvent-free conditions, followed by the anion exchange reaction with $\mathrm{KPF}_{6}$. After that, DILs were obtained by the alkylation of $\left[(\mathrm{PYR}) \mathrm{C}_{n} \mathrm{Cl}\right]\left[\mathrm{PF}_{6}\right]$ with one equivalent of 1-methylimidazole or pyridine to afford symmetrical and unsymmetrical dicationic compounds such as $\left[\mathrm{PF}_{6}\right]\left[(\mathrm{PYR}) \mathrm{C}_{n}(\mathrm{PYR})\right][\mathrm{Cl}]$ and $\left[\mathrm{PF}_{6}\right]\left[(\mathrm{PYR}) \mathrm{C}_{n}(\mathrm{MIM})\right][\mathrm{Cl}]$. Monocationic acidic ILs were obtained by the alkylation of 1-methylimidazole or pyridine with 3-chloropropionic acid, followed by the anion metathesis with $\mathrm{KPF}_{6}$ to give $\left[(\mathrm{PYR}) \mathrm{C}_{2} \mathrm{COOH}\right]\left[\mathrm{PF}_{6}\right]$ and $\left[(\mathrm{MIM}) \mathrm{C}_{2} \mathrm{COOH}\right]\left[\mathrm{PF}_{6}\right]$ (Scheme 2).

In the synthetic process of DILs, pyridine as the weak nucleophile was used in the first step, because it replaced only one chloride of dichloroalkane, whereas stronger nucleophiles such as 1-methylimidazole would attach both sides of the dichloroalkane. However, a yield of product, for example, [Cl] $\left[(\mathrm{PYR}) \mathrm{C}_{n}(\mathrm{PYR})\right][\mathrm{Cl}]$ was still observed, which was isolated by the column chromatography $\left(\mathrm{CH}_{2} \mathrm{Cl}_{2} / \mathrm{MeOH}=3 / 1\right)$.

\section{Thermal stability}

Thermal stability and melting points of ILs were determined and the results were presented in Table 1 and Fig. 1. Generally, unsymmetrical dicationic ILs containing 1-methylimidazolium group, e.g. $\left[\mathrm{PF}_{6}\right]\left[(\mathrm{PYR}) \mathrm{C}_{4}(\mathrm{MIM})\right][\mathrm{Cl}]\left(237^{\circ} \mathrm{C}\right)$ were more stable than those symmetrical dicationic ILs containing the pyridinium ring, e.g. $\left[\mathrm{PF}_{6}\right]\left[(\mathrm{PYR}) \mathrm{C}_{4}(\mathrm{PYR})\right][\mathrm{Cl}]\left(235^{\circ} \mathrm{C}\right)$, possibly due to the better nucleophilic capability of 1-methylimidazolium

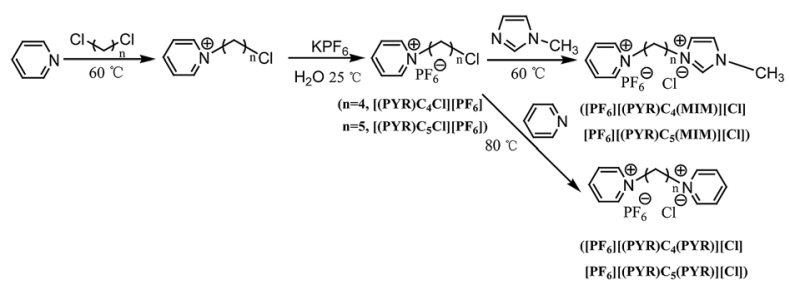

Scheme 1 Synthetic routes of dicationic ILs.

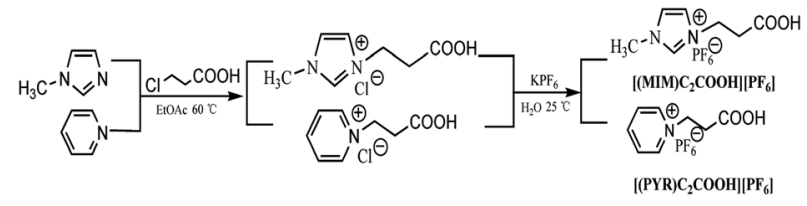

Scheme 2 Synthetic routes of monocationic ILs.

than pyridinium..$^{32-36} \mathrm{~A}$ similar study showed that the thermal stability of $\left[\mathrm{PF}_{6}\right]\left[(\mathrm{PYR}) \mathrm{C}_{3}(\mathrm{MIM})\right][\mathrm{Br}]$ was $252{ }^{\circ} \mathrm{C}$, which was higher than that of $\left[\mathrm{C}_{3}(\mathrm{PYR})_{2}\right][\mathrm{Br}]_{2}\left(240{ }^{\circ} \mathrm{C}\right) .{ }^{37}$ Less thermal stability was also obtained for $\left[(\mathrm{PYR}) \mathrm{C}_{2} \mathrm{COOH}\right]\left[\mathrm{PF}_{6}\right]$ compared with $\left[(\mathrm{MIM}) \mathrm{C}_{2} \mathrm{COOH}\right]\left[\mathrm{PF}_{6}\right]$ in this work. The low thermal stability was caused for monocationic acidic ILs by introducing of the carboxyl group.

In addition, an impact of the symmetry of the linkage chain of the dication on the thermal stability was observed.$^{38}$ A slight decrease of thermal stability was obtained for $\left[\mathrm{PF}_{6}\right][(\mathrm{PYR})$ $\left.\mathrm{C}_{5}(\mathrm{MIM})\right][\mathrm{Cl}]$ and $\left[\mathrm{PF}_{6}\right]\left[(\mathrm{PYR}) \mathrm{C}_{5}(\mathrm{PYR})\right][\mathrm{Cl}]$ than that of $\left[\mathrm{PF}_{6}\right]$ $\left[(\mathrm{PYR}) \mathrm{C}_{4}(\mathrm{MIM})\right][\mathrm{Cl}]$ and $\left[\mathrm{PF}_{6}\right]\left[(\mathrm{PYR}) \mathrm{C}_{4}(\mathrm{PYR})\right][\mathrm{Cl}]$.

\section{Melting points}

As shown in Table 1, symmetrical dicationic ILs containing pyridinium group $\left(\left[\mathrm{PF}_{6}\right]\left[(\mathrm{PYR}) \mathrm{C}_{4}(\mathrm{PYR})\right][\mathrm{Cl}]\right)\left(160.9{ }^{\circ} \mathrm{C}\right)$ have higher melting points than unsymmetrical dicationic ILs with imidazolium ring $\left(\left[\mathrm{PF}_{6}\right]\left[(\mathrm{PYR}) \mathrm{C}_{4}(\mathrm{MIM})\right][\mathrm{Cl}]\right)\left(98.3{ }^{\circ} \mathrm{C}\right)$. As suggested by Welton and Wasserscheid, this may be attributed to the relative degree of charge dispersion around the cation. Imidazolium has good charge dispersion compared with pyridine. ${ }^{35,39}$ A low symmetry of dication of $\left[\mathrm{PF}_{6}\right]\left[(\mathrm{PYR}) \mathrm{C}_{4}(\mathrm{MIM})\right][\mathrm{Cl}]$ also assisted the low melting point.

Previous reports indicated that the melting points of dicationic ILs decreased with the increase of alkyl linkage chain. ${ }^{40} \mathrm{It}$ was described that the melting point of $\left[\mathrm{C}_{3}(\mathrm{MIM})_{2}\right]\left[\mathrm{PF}_{6}\right]_{2}$ was $131{ }^{\circ} \mathrm{C}$, which was higher that of $\left[\mathrm{C}_{4}(\mathrm{MIM})_{2}\right]\left[\mathrm{PF}_{6}\right]_{2}\left(120{ }^{\circ} \mathrm{C}\right) .{ }^{27,37}$ In this study, $\left[(\mathrm{PYR}) \mathrm{C}_{5} \mathrm{Cl}\right]\left[\mathrm{PF}_{6}\right]$ that generated longer linkage chain displayed a lower melting point than that of $\left[(\mathrm{PYR}) \mathrm{C}_{4} \mathrm{Cl}\right]$ $\left[\mathrm{PF}_{6}\right]$. In addition, the symmetry of the linkage chain of the dication has a significant effect on the melting points. A reduced symmetry of linkage caused decreased melting points. As a result, $\left[\mathrm{PF}_{6}\right]\left[(\mathrm{PYR}) \mathrm{C}_{5}(\mathrm{MIM})\right][\mathrm{Cl}]$ and $\left[\mathrm{PF}_{6}\right]\left[(\mathrm{PYR}) \mathrm{C}_{5}(\mathrm{PYR})\right][\mathrm{Cl}]$

Table 1 Thermal decomposition temperature and melting points of $\mathrm{ILS}^{a}$

\begin{tabular}{lcr}
\hline ILs & $T_{\mathrm{d}}\left({ }^{\circ} \mathrm{C}\right)$ & $M_{\mathrm{p}}\left({ }^{\circ} \mathrm{C}\right)$ \\
\hline$\left[(\mathrm{PYR}) \mathrm{C}_{4} \mathrm{Cl}\right]\left[\mathrm{PF}_{6}\right]$ & 238 & 49.6 \\
{$\left[(\mathrm{PYR}) \mathrm{C}_{5} \mathrm{Cl}\right]\left[\mathrm{PF}_{6}\right]$} & 248 & 40.7 \\
{$\left[\mathrm{PF}_{6}\right]\left[(\mathrm{PYR}) \mathrm{C}_{4}(\mathrm{MIM})\right][\mathrm{Cl}]$} & 237 & 98.3 \\
{$\left[\mathrm{PF}_{6}\right]\left[(\mathrm{PYR}) \mathrm{C}_{4}(\mathrm{PYR})\right][\mathrm{Cl}]$} & 235 & 160.9 \\
{$\left[\mathrm{PF}_{6}\right]\left[(\mathrm{PYR}) \mathrm{C}_{5}(\mathrm{MIM})\right][\mathrm{Cl}]$} & 232 & 81.5 \\
{$\left[\mathrm{PF}_{6}\right]\left[(\mathrm{PYR}) \mathrm{C}_{5}(\mathrm{PYR})\right][\mathrm{Cl}]$} & 230 & 97.3 \\
{$\left[(\mathrm{MIM}) \mathrm{C}_{2} \mathrm{COOH}\right]\left[\mathrm{PF}_{6}\right]$} & 215 & 91.7 \\
{$\left[(\mathrm{PYR}) \mathrm{C}_{2} \mathrm{COOH}\right]\left[\mathrm{PF}_{6}\right]$} & 190 & 101.3 \\
${ }^{a} T_{\mathrm{d}}$ decomposition temperature; $M_{\mathrm{p}}$ melting points. &
\end{tabular}



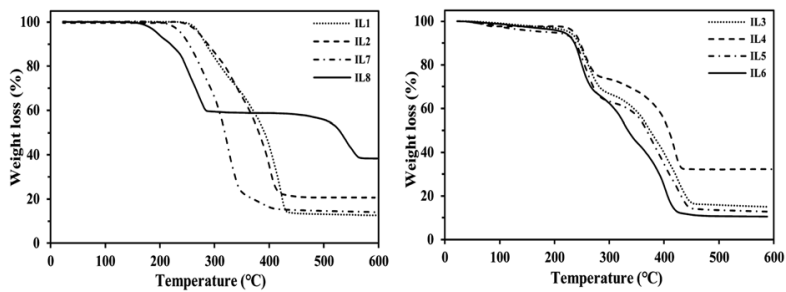

IL1: [(PYR) $\left.\mathrm{C}_{4} \mathrm{Cl}\right]\left[\mathrm{PF}_{6}\right]$; IL2: [(PYR $\left.) \mathrm{C}_{5} \mathrm{Cl}\right]\left[\mathrm{PF} \mathrm{F}_{6}\right]$;

IL3: [PF 6 ][(PYR) $\left.\mathrm{C}_{4}(\mathrm{MIM})\right][\mathrm{Cl}]$; IL4: [PF 6 ][(PYR) $\left.\mathrm{C}_{4}(\mathrm{PYR})\right][\mathrm{Cl}]$;

IL5: [PF 6 ] [(PYR) $C_{5}$ (MIM)][Cl]; IL6: [PF 6 ][(PYR) $C_{5}$ (PYR)][Cl];

IL7: [(MIM) $\left.\mathrm{C}_{2} \mathrm{COOH}\right]\left[\mathrm{PF}_{6}\right]$; IL8: [(PYR $\left.\mathrm{C}_{2} \mathrm{COOH}\right]\left[\mathrm{PF}_{6}\right]$

Fig. 1 Thermogravimetry curves of ILs.

exhibited lower melting points than that of $\left[\mathrm{PF}_{6}\right]\left[(\mathrm{PYR}) \mathrm{C}_{4}(\mathrm{MIM})\right]$ $[\mathrm{Cl}]$ and $\left[\mathrm{PF}_{6}\right]\left[(\mathrm{PYR}) \mathrm{C}_{4}(\mathrm{PYR})\right][\mathrm{Cl}]$.

\section{Solubility of ionic liquids with organic solvents}

The synthesized ILs were determined in several representative solvents at room temperature. As summarized in Table 2, both dicationic and monocationic ILs exhibited good solubility in high polar solvents, ${ }^{41}$ e.g. dimethyl sulfoxide (DMSO), but they were not soluble in non-polar solvents, e.g. diethyl ether $\left(\mathrm{Et}_{2} \mathrm{O}\right)$.

In this work, monocationic ILs generated better solubility than dicationic ILs. Monocationic ILs were soluble in most organic solvents. Dicationic ILs were not dissolved in methanol $(\mathrm{MeOH})$, ethanol (EtOH), and dichloromethane $\left(\mathrm{CH}_{2} \mathrm{Cl}_{2}\right)$. However, monocationic acidic ILs with carboxyl group were soluble in $\mathrm{MeOH}$, EtOH, but they were not soluble in $\mathrm{CH}_{2} \mathrm{Cl}_{2}$.

Particularly, imidazolium-based ILs displayed good solubility compared with pyridinium-based ILs. Dicationic ILs with imidazolium group were dissolved in acetonitrile $\left(\mathrm{CH}_{3} \mathrm{CN}\right)$ and acetone (DMK). In contrast, dicationic ILs with pyridinium ring were not soluble in $\mathrm{CH}_{3} \mathrm{CN}$ and DMK. Moreover, [(MIM) $\left.\mathrm{C}_{2} \mathrm{COOH}\right]\left[\mathrm{PF}_{6}\right]$ was soluble in $\mathrm{CH}_{3} \mathrm{CN}$ and DMK, whereas [(PYR) $\left.\mathrm{C}_{2} \mathrm{COOH}\right]\left[\mathrm{PF}_{6}\right]$ was not soluble in these two organic solvents.

Table 2 Solubility of ILs in various organic solvents ${ }^{a}$

\begin{tabular}{lllllllll}
\hline & DMSO & $\mathrm{MeOH}$ & $\mathrm{EtOH}$ & $\mathrm{CH}_{3} \mathrm{CN}$ & $\mathrm{DMK}$ & EtOAc & $\mathrm{CH}_{2} \mathrm{Cl}_{2}$ & $\mathrm{Et}_{2} \mathrm{O}$ \\
\hline $\mathrm{IL} 1$ & + & + & + & +++ & +++ & +++ & ++ & - \\
$\mathrm{IL} 2$ & + & + & + & +++ & +++ & +++ & ++ & - \\
IL3 & + & - & - & + & + & - & - & - \\
IL4 & + & - & - & - & - & - & - & - \\
IL5 & + & - & - & + & + & - & - & - \\
IL6 & + & - & - & - & - & - & - & - \\
IL7 & + & + & + & ++ & ++ & - & - & - \\
IL8 & + & + & + & - & - & - & - & -
\end{tabular}

${ }^{a}$ IL1: [(PYR)C $\left.\mathrm{C}_{4} \mathrm{Cl}\right]\left[\mathrm{PF}_{6}\right]$; IL2: [(PYR) $\left.\mathrm{C}_{5} \mathrm{Cl}\right]\left[\mathrm{PF}_{6}\right] ; \mathrm{IL} 3:\left[\mathrm{PF}_{6}\right]\left[(\mathrm{PYR}) \mathrm{C}_{4}(\mathrm{MIM})\right]$ [Cl]; IL4: [PF 6$]\left[(\mathrm{PYR}) \mathrm{C}_{4}(\mathrm{PYR})\right][\mathrm{Cl}]$; IL5: $\left[\mathrm{PF}_{6}\right]\left[(\mathrm{PYR}) \mathrm{C}_{5}(\mathrm{MIM})\right][\mathrm{Cl}]$; IL6: $\left[\mathrm{PF}_{6}\right]\left[(\mathrm{PYR}) \mathrm{C}_{5}(\mathrm{PYR})\right][\mathrm{Cl}] ; \quad$ IL7: $\quad\left[(\mathrm{MIM}) \mathrm{C}_{2} \mathrm{COOH}\right]\left[\mathrm{PF}_{6}\right] ; \quad$ IL8: [(PYR) $\left.\mathrm{C}_{2} \mathrm{COOH}\right]\left[\mathrm{PF}_{6}\right]$. "+++": $0.1 \mathrm{~g}$ ionic liquid was easily dissolved in the solvent $(<0.1 \mathrm{~mL})$. "++": $0.1 \mathrm{~g}$ ionic liquid was easily dissolved in the solvent $(0.1-1 \mathrm{~mL})$. "+": $0.1 \mathrm{~g}$ ionic liquids was dissolved in the solvent $(1-10 \mathrm{~mL})$. "-": $0.1 \mathrm{~g}$ ionic liquid was not dissolved in the solvent $(>10 \mathrm{~mL})$.
In current studies, the reported ILs were insoluble in ethyl acetate (EtOAc), because of their polar properties. Interestingly, $\left[(\mathrm{PYR}) \mathrm{C}_{4} \mathrm{Cl}\right]\left[\mathrm{PF}_{6}\right]$ and $\left[(\mathrm{PYR}) \mathrm{C}_{5} \mathrm{Cl}\right]\left[\mathrm{PF}_{6}\right]$ with haloalkyl chain were readily dissolved in EtOAc. Therefore, these ILs with different solubility could be selected and employed in various areas to satisfy different requirements.

\section{Miscibility of ionic liquids with water}

Generally, ILs with the anions of $\mathrm{PF}_{6}{ }^{-}$and $\mathrm{NTf}_{2}{ }^{-}$are waterimmiscible, whereas others are water-miscible. Interestingly, these dicationic and monocationic ILs are miscible with water at high temperatures and they are immiscible with water at low temperatures. It was found that dicationic ILs could form a homogeneous or heterogeneous system with water, depending on the dealing temperature.

As illustrated in Fig. 2, when the temperature was higher, the miscibility of dicationic ILs with water was better with a reduced amount of water. For example, $1.0 \mathrm{~g}$ of $\left[\mathrm{PF}_{6}\right]\left[(\mathrm{PYR}) \mathrm{C}_{4}(\mathrm{MIM})\right][\mathrm{Cl}]$ was miscible with $4 \mathrm{~mL}$ of water at $100{ }^{\circ} \mathrm{C}$. However, $105 \mathrm{~mL}$ of water was required at room temperature. Similarly, $6 \mathrm{~mL}$ of water was used to dissolve $1.0 \mathrm{~g}$ of $\left[\mathrm{PF}_{6}\right]\left[(\mathrm{PYR}) \mathrm{C}_{4}(\mathrm{PYR})\right][\mathrm{Cl}]$ at $100{ }^{\circ} \mathrm{C}$, whereas $232 \mathrm{~mL}$ of water was employed at room temperature.

Monocationic ILs were more soluble with water than dicationic ILs. For instance, $1.0 \mathrm{~g}$ of $\left[(\mathrm{PYR}) \mathrm{C}_{4} \mathrm{Cl}\right]\left[\mathrm{PF}_{6}\right]$ was miscible with $61 \mathrm{~mL}$ of water at room temperature, whereas $105 \mathrm{~mL}$ and $232 \mathrm{~mL}$ of water for $\left[\mathrm{PF}_{6}\right]\left[(\mathrm{PYR}) \mathrm{C}_{4}(\mathrm{MIM})\right][\mathrm{Cl}]$ and $\left[\mathrm{PF}_{6}\right][(\mathrm{PYR})$ $\left.\mathrm{C}_{4}(\mathrm{PYR})\right][\mathrm{Cl}]$ were required, respectively. Meanwhile, good miscibility was observed with imidazolium-based dicationic ILs than pyridinium-based dicationic ILs. Moreover, monocationic
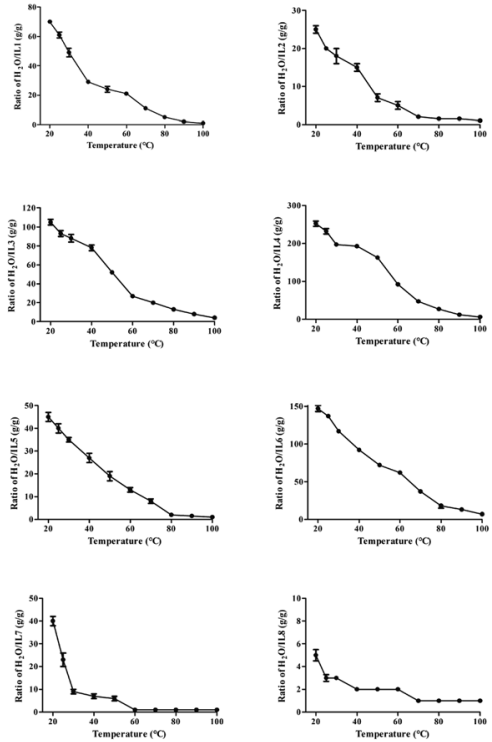

IL1: [(PYR) $\mathrm{C}_{4} \mathrm{Cl}_{[}\left[\mathrm{PF} \mathrm{F}_{6}\right] ;$ IL2: [(PYR $\left.\mathrm{C}_{5} \mathrm{Cl}\right]\left[\mathrm{PF}_{6}\right]$;

IL3: $\left[\mathrm{PF}_{6}\right]\left[(\mathrm{PYR}) \mathrm{C}_{4}(\mathrm{MIM})\right][\mathrm{Cl}]$; IL4: [PF6][(PYR) $\left.\mathrm{C}_{4}(\mathrm{PYR})\right][\mathrm{Cl}]$; IL5: [PF 6 ][(PYR) $\left.C_{5}(\mathrm{MIM})\right][\mathrm{Cl}]$; IL6: [PF 6 ][(PYR) $\left.\mathrm{C}_{5}(\mathrm{PYR})\right][\mathrm{Cl}]$; IL7: [(MIM) $\left.\mathrm{C}_{2} \mathrm{COOH}\right]\left[\mathrm{PF}_{6}\right]$; IL8: [(PYR) $\mathrm{C}_{2} \mathrm{COOH}_{[}\left[\mathrm{PF}_{6}\right]$

Fig. 2 Miscibility of ILs with water at different temperature. 
ILs containing carbonyl group $(-\mathrm{COOH})$ displayed better solubility than others, for example, $\left[(\mathrm{PYR}) \mathrm{C}_{2} \mathrm{COOH}\right]\left[\mathrm{PF}_{6}\right]$ was completely dissolved only with $5 \mathrm{~mL}$ of water under the assay condition. $^{42}$

With the enhance of cationic unsymmetry, the miscibility of dicationic ILs with water was increased (Fig. 2). Significantly, $105 \mathrm{~mL}$ of water was used to form a homogeneous system with $1.0 \mathrm{~g}$ of $\left[\mathrm{PF}_{6}\right]\left[(\mathrm{PYR}) \mathrm{C}_{4}(\mathrm{MIM})\right][\mathrm{Cl}]$ at room temperature. And yet, $45 \mathrm{~mL}$ was required for $1.0 \mathrm{~g}$ of $\left[\mathrm{PF}_{6}\right]\left[(\mathrm{PYR}) \mathrm{C}_{5}(\mathrm{MIM})\right][\mathrm{Cl}]$, because an increase of the of the linkage chain of dication improved the hydrophilic properties of dicationic ILs.

\section{Hydrolysis of corn stalk and potato starch in ILs}

Currently, ILs with the addition of mineral acids or functional acidic ILs for the treatment of biomass were reported. HernouxVillière et $a .^{43}$ found that the treatment of potato starch in aqueous 1-(4-sulfobutyl)-3-methylimidazolium chloride at $80{ }^{\circ} \mathrm{C}$ for $2 \mathrm{~h}$ produced $43 \%$ of the total reducing sugar. Seddon et al. ${ }^{\mathbf{4 4}}$ reported that the total yield of reducing sugar for potato starch was $54 \%$ with the Brønsted-acidic ionic liquids and was $6 \%$ with the 1-allyl-3-methylimidazolium chloride at $80{ }^{\circ} \mathrm{C}$ for $1 \mathrm{~h}$. In this study, a high yield of reducing sugar $(72.50 \%)$ for potato starch was achieved with the treatment of the mixture of $\left[\mathrm{PF}_{6}\right][(\mathrm{PYR})$ $\left.\mathrm{C}_{4}(\mathrm{PYR})\right][\mathrm{Cl}]$ and $\left[\mathrm{PF}_{6}\right]\left[(\mathrm{PYR}) \mathrm{C}_{2} \mathrm{COOH}\right]$ at $100{ }^{\circ} \mathrm{C}$ for $6 \mathrm{~h}$ (Fig. 3). However, when potato starch was treated with $\left[(\mathrm{PYR}) \mathrm{C}_{2} \mathrm{COOH}\right]$ $\left[\mathrm{PF}_{6}\right]$ or $\left[(\mathrm{MIM}) \mathrm{C}_{2} \mathrm{COOH}\right]\left[\mathrm{PF}_{6}\right]$ as a sole solvent at $100{ }^{\circ} \mathrm{C}$ for $6 \mathrm{~h}$, the yields of reducing sugar were $43.28 \%$ and $15.25 \%$, respectively.

In addition, Li et al. ${ }^{45}$ reported that corn stalk was hydrolyzed in 1-buty-3-methylimidazolium chloride with sulfuric acid as a catalyst at $100{ }^{\circ} \mathrm{C}$ for $6 \mathrm{~h}$ to give $37 \%$ of total reducing sugar. Ma et $a .^{\mathbf{4 6}}$ demonstrated that corn stalk was treated by $N$ methyl-2-pyrrolidonium methanesulfonate, $N$-methyl-2pyrrolidonium hydrogen sulfate and $N$-methyl-2pyrrolidonium chloride at $90{ }^{\circ} \mathrm{C}$ for $30 \mathrm{~min}$, and the resulting yield of reducing sugar was $23.51 \%, 22.26 \%$ and $20.19 \%$, respectively. In this study, a high yield of reducing sugar for corn stalk was achieved at $18.80 \%$ for $6 \mathrm{~h}$ (Fig. 3) and $20.73 \%$ for $8 \mathrm{~h}$ (Fig. 4) with the mixture of $\left[\mathrm{PF}_{6}\right]\left[(\mathrm{PYR}) \mathrm{C}_{4}(\mathrm{PYR})\right][\mathrm{Cl}]$ and $\left[(\mathrm{PYR}) \mathrm{C}_{2} \mathrm{COOH}\right]\left[\mathrm{PF}_{6}\right]$ at $100{ }^{\circ} \mathrm{C}$. Nevertheless, when corn stalk was treated with $\left[(\mathrm{PYR}) \mathrm{C}_{2} \mathrm{COOH}\right]\left[\mathrm{PF}_{6}\right]$ or $\left[(\mathrm{MIM}) \mathrm{C}_{2} \mathrm{COOH}\right]\left[\mathrm{PF}_{6}\right]$ as the sole solvent at $100{ }^{\circ} \mathrm{C}$ for $6 \mathrm{~h}$, the yields of reducing sugar were $6.94 \%$ and $6.50 \%$, respectively.

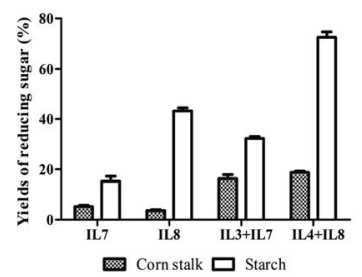

IL3: $\left[\mathrm{PF}_{6}\right]\left[(\mathrm{PYR}) \mathrm{C}_{4}(\mathrm{MIM})\right][\mathrm{Cl}]$; IL4: [PF 6$]\left[(\mathrm{PYR}) \mathrm{C}_{4}(\mathrm{PYR})\right][\mathrm{Cl}]$; IL7: [(MIM) $\left.\mathrm{C}_{2} \mathrm{COOH}\right]\left[\mathrm{PF}_{6}\right]$; IL8: [(PYR) $\left.\mathrm{C}_{2} \mathrm{COOH}\right]\left[\mathrm{PF}_{6}\right]$

Fig. 3 Yields of reducing sugar after ILs-treatment.
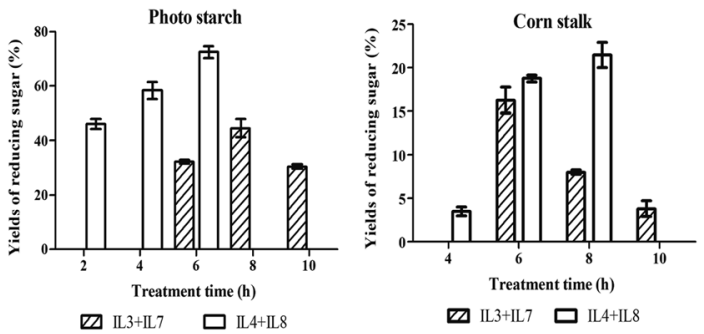

IL3: $\left[\mathrm{PF}_{6}\right]\left[(\mathrm{PYR}) \mathrm{C}_{4}(\mathrm{MIM})\right][\mathrm{Cl}]$; IL4: [PF $]\left[(\mathrm{PYR}) \mathrm{C}_{4}(\mathrm{PYR})\right][\mathrm{Cl}]$;

IL7: [(MIM) $\left.\mathrm{C}_{2} \mathrm{COOH}\right]\left[\mathrm{PF}_{6}\right]$; IL8: [(PYR) $\left.\mathrm{C}_{2} \mathrm{COOH}\right]\left[\mathrm{PF}_{6}\right]$

Fig. 4 Yields of reducing sugar for different treatment time.

Initially, as the treatment time was increased, the total yield of reducing sugar was increased (Fig. 4). When the treatment time for potato starch was increased from $2 \mathrm{~h}$ to $6 \mathrm{~h}$, the yield of reducing sugar was improved from $47.60 \%$ to $72.50 \%$ with the mixture of $\left[\mathrm{PF}_{6}\right]\left[(\mathrm{PYR}) \mathrm{C}_{4}(\mathrm{PYR})\right][\mathrm{Cl}]$ and $\left[(\mathrm{PYR}) \mathrm{C}_{2} \mathrm{COOH}\right]\left[\mathrm{PF}_{6}\right]$. With the same ILs, as the treatment time for corn stalk was increased from $4 \mathrm{~h}$ to $8 \mathrm{~h}$, the yield of reducing sugar was improved from $5.87 \%$ to $20.73 \%$. However, the yields of reducing sugar were reduced as the treatment time was increased with the mixture of $\left[\mathrm{PF}_{6}\right]\left[(\mathrm{PYR}) \mathrm{C}_{4}(\mathrm{MIM})\right][\mathrm{Cl}]$ and $\left[(\mathrm{MIM}) \mathrm{C}_{2} \mathrm{COOH}\right]\left[\mathrm{PF}_{6}\right]$ from $8 \mathrm{~h}$ to $10 \mathrm{~h}$ for both potato starch and corn stalk.

Obviously, high yields of reducing sugar were obtained from potato starch and corn stalk with the mixture of dicationic ILs and monocationic acidic ILs. Monicationic ILs provided the acidic nature to assist the hydrolysis of potato starch and corn stalk. The basicity of one of the anion $\left(\mathrm{Cl}^{-}\right)$of dicationic ILs made it more efficient at disrupting inter- and intra-molecular hydrogen bonding in polymers. The other anion $\left(\mathrm{PF}_{6}{ }^{-}\right)$of dicationic ILs provided the hydrophobic and hydrophilic properties at different temperature. In current studies, all the ILs used for polymers-hydrolysis and biomass-treatment are hydrophilic, which increase the difficulty of the isolation of sugar and reuse of ILs. The variable miscibility of these functional ILs with water in this work provided the opportunity for hydrolysis of various carbohydrate polymers.

\section{Reuse of ionic liquids}

The feasibility and sustainable development of any catalytic process depends on the reusability of catalysts and solvents. Generally, after ILs-treatment of biomass, reducing sugar was readily extracted by the addition of water at a low temperature. However, a yield of monocationic acidic ILs would be lost in the aqueous layer. Further work will focus on the design of functional acidic ILs to increase their hydrophobic property. Alternatively, both of $\left[\mathrm{PF}_{6}\right]\left[(\mathrm{PYR}) \mathrm{C}_{4}(\mathrm{MIM})\right][\mathrm{Cl}]$ and $\left[(\mathrm{MIM}) \mathrm{C}_{2} \mathrm{COOH}\right]$ $\left[\mathrm{PF}_{6}\right]$ could be simply extracted with acetonitrile, which were readily reused after the removal of acetonitrile. Otherwise, monocationic acidic $\left[(\mathrm{PYR}) \mathrm{C}_{2} \mathrm{COOH}\right]\left[\mathrm{PF}_{6}\right]$ or $\left[(\mathrm{MIM}) \mathrm{C}_{2} \mathrm{COOH}\right]$ $\left[\mathrm{PF}_{6}\right]$ could be extracted with methanol. After the isolation of reducing sugar with water at room temperature, an amount of deionized water was added into the mixture with heating and 

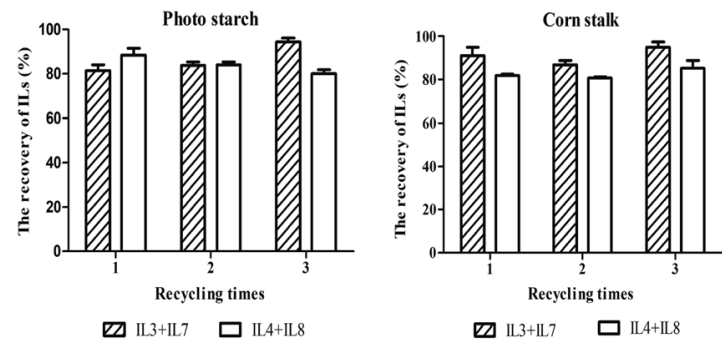

IL3: [PF 6 ][(PYR) $\left.\mathrm{C}_{4}(\mathrm{MIM})\right][\mathrm{Cl}]$; IL4: $\left[\mathrm{PF}_{6}\right]\left[(\mathrm{PYR}) \mathrm{C}_{4}(\mathrm{PYR})\right][\mathrm{Cl}]$; IL7: [(MIM) $\left.\mathrm{C}_{2} \mathrm{COOH}\right]\left[\mathrm{PF}_{6}\right] ;$ IL8: [(PYR $\mathrm{C}_{2} \mathrm{COOH}\left[\mathrm{PF}_{6}\right]$

Fig. 5 The recovery of ILs.

stirring to provide $\left[\mathrm{PF}_{6}\right]\left[(\mathrm{PYR}) \mathrm{C}_{4}(\mathrm{PYR})\right][\mathrm{Cl}]$. As shown in Fig. 5 , high re-covery of ILs including $\left[\mathrm{PF}_{6}\right]\left[(\mathrm{PYR}) \mathrm{C}_{4}(\mathrm{PYR})\right][\mathrm{Cl}]$ and $\left[(\mathrm{PYR}) \mathrm{C}_{2} \mathrm{COOH}\right]\left[\mathrm{PF}_{6}\right]$ were obtained in the range of $80.20 \%$ to $88.37 \%$ for potato starch and $80.73 \%$ to $85.27 \%$ for corn stalk. Good recovery of ILs including $\left[\mathrm{PF}_{6}\right]\left[(\mathrm{PYR}) \mathrm{C}_{4}(\mathrm{MIM})\right][\mathrm{Cl}]$ and $\left[(\mathrm{MIM}) \mathrm{C}_{2} \mathrm{COOH}\right]\left[\mathrm{PF}_{6}\right]$ were achieved in the range of $81.45 \%$ to $94.49 \%$ for potato starch and $86.76 \%$ to $94.91 \%$ for corn stalk.

In this work, no significant reduced yields of reducing sugar was observed. The rates of reducing sugar for potato starch were $100 \%$ (1st run), $82.41 \%$ (2nd run) and $73.69 \%$ (3rd run) with the treatment of $\left[\mathrm{PF}_{6}\right]\left[(\mathrm{PYR}) \mathrm{C}_{4}(\mathrm{PYR})\right][\mathrm{Cl}]$ and $\left[(\mathrm{PYR}) \mathrm{C}_{2} \mathrm{COOH}\right]\left[\mathrm{PF}_{6}\right]$ and were $100 \%$ (1st run), $83.13 \%$ (2nd run) and $90.00 \%$ (3rd run) with the treatment of $\left[\mathrm{PF}_{6}\right]\left[(\mathrm{PYR}) \mathrm{C}_{4}(\mathrm{MIM})\right][\mathrm{Cl}]$ and $[(\mathrm{MIM})$ $\left.\mathrm{C}_{2} \mathrm{COOH}\right]\left[\mathrm{PF}_{6}\right]$ (Fig. 6). Similarly, the rates of reducing sugar for corn stalk were $100 \%$ (1st run), $75.10 \%$ (2nd run) and $79.05 \%$ (3rd run) with the treatment of $\left[\mathrm{PF}_{6}\right]\left[(\mathrm{PYR}) \mathrm{C}_{4}(\mathrm{PYR})\right][\mathrm{Cl}]$ and $\left[(\mathrm{PYR}) \mathrm{C}_{2} \mathrm{COOH}\right]\left[\mathrm{PF}_{6}\right]$ and were $100 \%$ (1st run), $71.91 \%$ (2nd run) and $70.02 \%$ (3rd run) with the treatment of $\left[\mathrm{PF}_{6}\right]\left[(\mathrm{PYR}) \mathrm{C}_{4}(\mathrm{MIM})\right]$ $[\mathrm{Cl}]$ and $\left[(\mathrm{MIM}) \mathrm{C}_{2} \mathrm{COOH}\right]\left[\mathrm{PF}_{6}\right]$.

\section{Experimental}

\section{Materials}

1-Methylimidazole (99\%), pyridine (99\%), 1,4-dichlorobutane (99\%), 1,5-dichloropentane (99\%), 3-chloropropionic acid (99\%), potassium hexafluorophosphate (99\%) were purchased from Aldrich Reagent Co., Ltd (Shanghai, China). All the reagents were used without further purification. Corn stalk was supplied by local farm in Harbin City (China), milled to pass
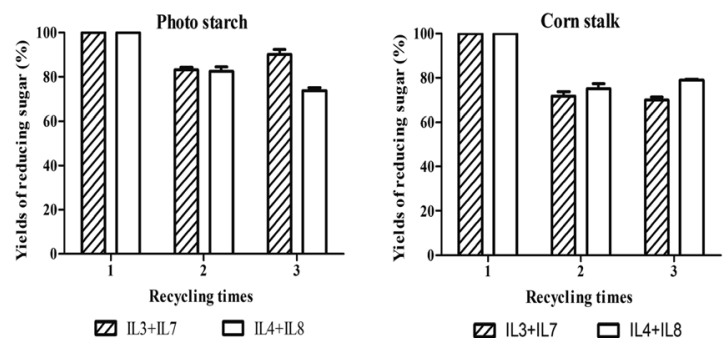

IL3: [PF 6 ][(PYR) $\left.\mathrm{C}_{4}(\mathrm{MIM})\right][\mathrm{Cl}]$; IL4: [PF 6 ][(PYR) $\left.\mathrm{C}_{4}(\mathrm{PYR})\right][\mathrm{Cl}]$; IL7: [(MIM) $\left.\mathrm{C}_{2} \mathrm{COOH}\right]\left[\mathrm{PF}_{6}\right]$; IL8: [(PYR) $\mathrm{C}_{2} \mathrm{COOH}_{[}\left[\mathrm{PF}_{6}\right]$

Fig. 6 The rates of reducing sugar after three cycles. through 40 mesh sieves and dried at $60{ }^{\circ} \mathrm{C}$ for $24 \mathrm{~h}$. Potato starch was purchased from Tianjin Kaitong Chemical Reagent Co., Ltd (Tianjin, China).

\section{Synthesis of ionic liquids}

[1-(4-Chlorobutyl) pyridinium] hexafluorophosphate [(PYR) $\left.\mathbf{C}_{4} \mathbf{C l}\right]\left[\mathbf{P F}_{6}\right]$. Pyridine $(1.0 \mathrm{mmol})$ and 1, 4-dichlorobutane (1.2 $\mathrm{mmol}$ ) were stirred at $60^{\circ} \mathrm{C}$ for 4 days. The resulting precipitate was filtered and washed with ethyl acetate, which was further purified by silica column chromatography $\left(\mathrm{CH}_{2} \mathrm{Cl}_{2} / \mathrm{MeOH}=3\right.$ / 1) and was dried at $60{ }^{\circ} \mathrm{C}$ under vacuum for $4 \mathrm{~h}$. After that, the precipitate $(1.0 \mathrm{mmol})$ was reacted with $\mathrm{KPF}_{6}(1.5 \mathrm{mmol})$ in deionized water at room temperature for $3 \mathrm{~h}$. The resulting product was washed with deionized water and was dried in a vacuum for $12 \mathrm{~h}$. [1-(5-Chloropentyl) pyridinium] hexafluorophosphate $\left[(\mathrm{PYR}) \mathrm{C}_{5} \mathrm{Cl}\right]\left[\mathrm{PF}_{6}\right]$ was prepared using a similar method as $\left[(\mathrm{PYR}) \mathrm{C}_{4} \mathrm{Cl}\right]\left[\mathrm{PF}_{6}\right]$.

$\left[(\mathrm{PYR}) \mathrm{C}_{4} \mathrm{Cl}\right]\left[\mathrm{PF}_{6}\right]:{ }^{1} \mathrm{H}-\mathrm{NMR}$ (400 MHz, DMSO-d $\left.{ }_{6}\right)(\mathrm{ppm}): 9.34$ $(\mathrm{m}, 2 \mathrm{H}), 8.63(\mathrm{t}, 1 \mathrm{H}), 8.19(\mathrm{~m}, 2 \mathrm{H}), 4.77(\mathrm{t}, 2 \mathrm{H}), 3.66(\mathrm{t}, 2 \mathrm{H}), 2.03$ $(\mathrm{m}, 2 \mathrm{H}), 1.71(\mathrm{~m}, 2 \mathrm{H})$.

[(PYR) $\left.\mathrm{C}_{5} \mathrm{Cl}\right]\left[\mathrm{PF}_{6}\right]:{ }^{1} \mathrm{H}-\mathrm{NMR}\left(400 \mathrm{MHz}, \mathrm{DMSO}-\mathrm{d}_{6}\right)(\mathrm{ppm}): 9.09$ $(\mathrm{d}, 2 \mathrm{H}), 8.60(\mathrm{t}, 1 \mathrm{H}), 8.17(\mathrm{t}, 2 \mathrm{H}), 4.61(\mathrm{t}, 2 \mathrm{H}), 3.65(\mathrm{t}, 2 \mathrm{H}), 1.95$ (quint, 2H), $1.76(\mathrm{~m}, 2 \mathrm{H}), 1.39(\mathrm{~m}, 2 \mathrm{H})$.

Hexafluorophosphate [1-(1-pyridinium-yl-butyl)-4methylimidazolium] chloride $\left[\mathrm{PF}_{6}\right]\left[\left([\mathrm{PYR}) \mathrm{C}_{4}(\mathrm{MIM})\right][\mathrm{Cl}]\right.$. [(PYR) $\left.\mathrm{C}_{4} \mathrm{Cl}\right]\left[\mathrm{PF}_{6}\right](3.16 \mathrm{~g})$ and 1-methylimidazolium $(0.1 \mathrm{mmol})$ were added into $2 \mathrm{~mL}$ of ethyl acetate. The reaction proceeded at $60{ }^{\circ} \mathrm{C}$ for $24 \mathrm{~h}$. The desired product was purified by recrystallize of acetonitrile/ethyl acetate $(1 / 10)$ and then was dried in a vacuum at $60{ }^{\circ} \mathrm{C}$ for $4 \mathrm{~h}$. Hexafluorophosphate [1-(1pyridinium-yl-pentyl)-5-methylimidazolium $]$ chloride $\left[\mathrm{PF}_{6}\right]$ $\left[(\mathrm{PYR}) \mathrm{C}_{5}(\mathrm{MIM})\right][\mathrm{Cl}]$ was synthesized using a similar method as $\left[\mathrm{PF}_{6}\right]\left[(\mathrm{PYR}) \mathrm{C}_{4}(\mathrm{MIM})\right][\mathrm{Cl}]$.

$\left[\mathrm{PF}_{6}\right]\left[(\mathrm{PYR}) \mathrm{C}_{4}(\mathrm{MIM})\right][\mathrm{Cl}]:{ }^{1} \mathrm{H}-\mathrm{NMR} \quad\left(400 \mathrm{MHz}, \quad\right.$ DMSO-d $\left.{ }_{6}\right)$ (ppm): $9.42(\mathrm{~s}, 1 \mathrm{H}), 9.26(\mathrm{~d}, 2 \mathrm{H}), 8.60(\mathrm{t}, 1 \mathrm{H}), 8.16(\mathrm{t}, 2 \mathrm{H}), 7.84(\mathrm{~s}$, $1 \mathrm{H}), 7.74(\mathrm{~s}, 1 \mathrm{H}), 4.74(\mathrm{t}, 2 \mathrm{H}), 4.27(\mathrm{t}, 2 \mathrm{H}), 3.85(\mathrm{~s}, 3 \mathrm{H}), 1.92$ (quint, 2H), 1.83 (quint, $2 \mathrm{H}$ ).

$\left[\mathrm{PF}_{6}\right]\left[(\mathrm{PYR}) \mathrm{C}_{5}(\mathrm{MIM})\right][\mathrm{Cl}]:{ }^{1} \mathrm{H}-\mathrm{NMR} \quad\left(400 \mathrm{MHz}, \quad\right.$ DMSO-d $\left.\mathrm{d}_{6}\right)$ (ppm): $9.43(\mathrm{~s}, 1 \mathrm{H}), 9.27(\mathrm{~d}, 2 \mathrm{H}), 8.59(\mathrm{~m}, 1 \mathrm{H}), 8.14(\mathrm{~m}, 2 \mathrm{H}), 7.84$ $(\mathrm{s}, 1 \mathrm{H}), 7.72(\mathrm{~s}, 1 \mathrm{H}), 4.67(\mathrm{~m}, 2 \mathrm{H}), 4.19(\mathrm{~m}, 2 \mathrm{H}), 3.85(\mathrm{~s}, 3 \mathrm{H}), 1.96$ $(\mathrm{m}, 2 \mathrm{H}), 1.83(\mathrm{~m}, 2 \mathrm{H}), 1.23(\mathrm{~m}, 2 \mathrm{H})$.

Hexafluorophosphate [1-(1-pyridinium-yl-butyl)-4pyridinium $]$ chloride $\left[\mathrm{PF}_{6}\right]\left[(\mathrm{PYR}) \mathrm{C}_{4}(\mathrm{PYR})\right][\mathrm{Cl}]$. $\left[(\mathrm{PYR}) \mathrm{C}_{4} \mathrm{Cl}\right]\left[\mathrm{PF}_{6}\right]$ $(0.1 \mathrm{mmol})$ was reacted with pyridinium $(0.12 \mathrm{mmol})$ at $80^{\circ} \mathrm{C}$ for $24 \mathrm{~h}$. Following that, the product was recrystallized with acetonitrile/ethyl acetate $(1 / 10)$ and dried in a vacuum at $60{ }^{\circ} \mathrm{C}$ for $4 \mathrm{~h}$. Hexafluorophosphate [1-(1-pyridinium-yl-pentyl)-5pyridinium $]$ chloride $\left(\left[\mathrm{PF}_{6}\right]\left[(\mathrm{PYR}) \mathrm{C}_{5}(\mathrm{PYR})\right][\mathrm{Cl}]\right)$ was prepared using a similar method as $\left[\mathrm{PF}_{6}\right]\left[(\mathrm{PYR}) \mathrm{C}_{4}(\mathrm{PYR})\right][\mathrm{Cl}]$.

$\left[\mathrm{PF}_{6}\right]\left[(\mathrm{PYR}) \mathrm{C}_{4}(\mathrm{PYR})\right][\mathrm{Cl}]:{ }^{1} \mathrm{H}-\mathrm{NMR} \quad(400 \mathrm{MHz}, \quad$ DMSO-d 6 ) (ppm): $9.19(\mathrm{~m}, 4 \mathrm{H}), 8.62(\mathrm{t}, 2 \mathrm{H}), 8.17(\mathrm{t}, 4 \mathrm{H}), 4.69(\mathrm{t}, 4 \mathrm{H}), 1.97$ (quint, $4 \mathrm{H}$ ).

$\left[\mathrm{PF}_{6}\right]\left[(\mathrm{PYR}) \mathrm{C}_{5}(\mathrm{PYR})\right][\mathrm{Cl}]:{ }^{1} \mathrm{H}-\mathrm{NMR} \quad(400 \mathrm{MHz}, \quad$ DMSO-d 6 ) (ppm): $9.25(\mathrm{~d}, 4 \mathrm{H}), 8.60(\mathrm{t}, 2 \mathrm{H}), 8.17(\mathrm{t}, 4 \mathrm{H}), 4.67(\mathrm{t}, 4 \mathrm{H}), 1.99$ (quint, $4 \mathrm{H}), 1.31(\mathrm{t}, 2 \mathrm{H})$. 
[1-(2-Carboxylpropyl)-1-methylimidazolium] hexafluorophosphate $\left[(\mathbf{M I M}) \mathbf{C}_{2} \mathbf{C O O H}\right]\left[\mathbf{P F}_{6}\right]$. Methylimidazolium $(0.4 \mathrm{~mol})$ was dropped slowly into 3-chloropropionic acid (0.4 mol) in $200 \mathrm{~mL}$ of ethyl acetate. The mixture was stirred constantly at $70{ }^{\circ} \mathrm{C}$ for $24 \mathrm{~h} .{ }^{47}$ The resulting product was washed with ethyl acetate $(20 \mathrm{~mL} \times 3)$ to give $\left[(\mathrm{MIM}) \mathrm{C}_{2} \mathrm{COOH}\right][\mathrm{Cl}]$. $\left[(\mathrm{MIM}) \mathrm{C}_{2} \mathrm{COOH}\right][\mathrm{Cl}](0.1 \mathrm{mmol})$ was reacted with hexafluorophosphate $(0.1 \mathrm{mmol})$ in $30 \mathrm{~mL}$ of deionized water at room temperature for $3 \mathrm{~h}$. The product was filtered and dried at $50{ }^{\circ} \mathrm{C}$ for $12 \mathrm{~h}$ to obtain $\left[(\mathrm{MIM}) \mathrm{C}_{2} \mathrm{COOH}\right]\left[\mathrm{PF}_{6}\right]$. [1-(2Carboxylpropyl)-pyridinium] hexafluorophosphate [(PYR) $\left.\mathrm{C}_{2} \mathrm{COOH}\right]\left[\mathrm{PF}_{6}\right]$ was synthesized using a similar method as $\left[(\mathrm{MIM}) \mathrm{C}_{2} \mathrm{COOH}\right]\left[\mathrm{PF}_{6}\right]$.

$\left[(\mathrm{MIM}) \mathrm{C}_{2} \mathrm{COOH}\right]\left[\mathrm{PF}_{6}\right]:{ }^{1} \mathrm{H}-\mathrm{NMR}\left(400 \mathrm{MHz}, \mathrm{DMSO}-\mathrm{d}_{6}\right)(\mathrm{ppm})$ : $9.11(\mathrm{~s}, 1 \mathrm{H}), 7.76(\mathrm{~s}, 1 \mathrm{H}), 7.68(\mathrm{~s}, 1 \mathrm{H}), 4.35(\mathrm{t}, 2 \mathrm{H}), 3.85(\mathrm{~s}, 3 \mathrm{H})$, $2.89(\mathrm{t}, 2 \mathrm{H})$.

$\left[(\mathrm{PYR}) \mathrm{C}_{2} \mathrm{COOH}\right]\left[\mathrm{PF}_{6}\right]:{ }^{1} \mathrm{H}-\mathrm{NMR}\left(400 \mathrm{MHz}\right.$, DMSO-d $\left.\mathrm{d}_{6}\right)(\mathrm{ppm}):$ 9.14(d, $2 \mathrm{H}), 8.60(\mathrm{t}, 1 \mathrm{H}), 8.15(\mathrm{t}, 2 \mathrm{H}), 4.80(\mathrm{t}, 2 \mathrm{H}), 3.10(\mathrm{t}, 2 \mathrm{H})$.

\section{Thermal stability analysis}

The thermal behavior of ionic liquids was investigated using a TG 209 F3 thermogravimetric analyzer (NETZSCH, Germany) by heating $10 \mathrm{mg}$ of sample over temperature range from ambient to about $600{ }^{\circ} \mathrm{C}$ in nitrogen at a scanning rate of $10^{\circ} \mathrm{C} \mathrm{min}^{-1}$. The melting points were determined using a XPL-2 polarizing microscope melting point apparatus (NOVEL, China). ${ }^{48-51}$

\section{Solubility of ionic liquids with organic solvents}

The ionic liquid $(0.1 \mathrm{~g})$ was mixed with one of organic solvents $(10 \mathrm{~mL})$. The mixture was shaking strongly using magnetic stirrer for $30 \mathrm{~min}$ at room temperature. If the ionic liquid was insoluble in the organic solvent, which was added further until the ionic liquid was completely dissolved. The volumes of the organic solvent were recorded.

\section{Miscibility of ionic liquids with water}

The ionic liquid $(1.0 \mathrm{~g})$ was mixed with deionized water $(1 \mathrm{~mL})$. The mixture was stirred with $200 \mathrm{rpm}$ for $30 \mathrm{~min}$ at different temperature. If the ionic liquid was immiscible with deionized water, the deionized water was added into the mixture further, which was repeated until it become a clear solution. The volumes of water were recorded. ${ }^{27}$

\section{Treatment of corn stalk and potato starch}

Corn stalk or potato starch $(200 \mathrm{mg})$ was added into the mixture containing the dicationic ILs ( $3 \mathrm{~g})$, monocationic acidic ILs ( $1 \mathrm{~g}$ ) and deionized water $(1.5 \mathrm{~mL})$. The mixture was stirred at $100{ }^{\circ} \mathrm{C}$ for $6 \mathrm{~h}$ in a reaction kettle in an oil bath. After that, $15 \mathrm{~mL}$ of deionized water was added to the mixture when the reaction was finished. The supernatant by centrifugation was used for the determination of reducing sugar. The yield of reducing sugar was calculated as eqn (1):

$$
=\frac{\begin{array}{c}
\text { Reducing sugar }(\%) \\
\text { Reducing sugar }(\mathrm{mg})
\end{array}}{\text { Sample subjected to treatment }(\mathrm{mg})} 100
$$

\section{Reuse of ionic liquids}

Corn stalk or potato starch $(200 \mathrm{mg})$ was treated with the mixture containing the dicationic ILs $(3 \mathrm{~g})$, monocationic acidic ILs $(1 \mathrm{~g})$ and deionized water $(1.5 \mathrm{~mL})$ at $100^{\circ} \mathrm{C}$ for $6 \mathrm{~h}$ in a reaction kettle in an oil bath. After that, the mixture in a kettle was dried at $60^{\circ} \mathrm{C}$ for $6 \mathrm{~h} .20 \mathrm{~mL}$ of acetonitrile was added into the mixture. The filtrate was collected and acetonitrile was evaporated to give $\left[(\mathrm{MIM}) \mathrm{C}_{2} \mathrm{COOH}\right]\left[\mathrm{PF}_{6}\right]$ and $\left[\mathrm{PF}_{6}\right]$ $\left[(\mathrm{PYR}) \mathrm{C}_{4}(\mathrm{MIM})\right][\mathrm{Cl}]$. The reducing sugar was then obtained by the addition of deionized water $(20 \mathrm{~mL})$. Otherwise, $20 \mathrm{~mL}$ of methanol was added into the mixture. The filtrate was collected and methanol was evaporated to give [(PYR) $\left.\mathrm{C}_{2} \mathrm{COOH}\right]\left[\mathrm{PF}_{6}\right]$. The reducing sugar was then obtained by the addition of deionized water $(20 \mathrm{~mL})$. Following that, $60 \mathrm{~mL}$ of deionized water was added into the filtered solid with stirring and heating at $100{ }^{\circ} \mathrm{C}$. In practical application, when a small amount of water was evaporated, $\left[\mathrm{PF}_{6}\right]\left[(\mathrm{PYR}) \mathrm{C}_{4}(\mathrm{PYR})\right][\mathrm{Cl}]$ will precipitate out of the solution at a low temperature, which can be obtained through filtration. In order to obtain the accurate yield for reuse, all water was evaporated instead of the precipitation. All products were further dried in a vacuum at $60{ }^{\circ} \mathrm{C}$ for $6 \mathrm{~h}$. The rate of reducing sugar was calculated as eqn (2):

$$
=\frac{\text { Rate of reducing sugar }(\%)}{\text { Yields of reducing sugar after any treatment }(\mathrm{mg})} 100
$$

\section{Conclusions}

Dicaionic and monocationic ILs with variable miscibility with water at different temperatures were synthesized. These functional ILs have important implications in the design of homogeneous and heterogeneous system with water and organic solvents, which will greatly benefit some specific applications. Particularly, the mixture of $\left[\mathrm{PF}_{6}\right][(\mathrm{PYR})$ $\left.\mathrm{C}_{4}(\mathrm{PYR})\right][\mathrm{Cl}]$ and $\left[(\mathrm{PYR}) \mathrm{C}_{2} \mathrm{COOH}\right]\left[\mathrm{PF}_{6}\right]$ played a crucial effect on the hydrolysis of carbohydrate polymers. Total reducing sugar was up to $72.50 \%$ for potato starch after $6 \mathrm{~h}$ and $20.73 \%$ for corn stalk after $8 \mathrm{~h}$. respectively. The recovery of ILs were higher than $80 \%$ and the rates of reducing sugar were more than $70 \%$ after three cycles. The variable miscibility of these functional ILs with water provides the possibility for polymers-hydrolysis, biomass-treatment and other industrial specific utilizations.

\section{Conflicts of interest}

There are no conflicts to declare. 


\section{Acknowledgements}

This work was financially supported by University Nursing Program for Young Scholars with Creative Talents in Heilongjiang Province (UNPYSCT-2017021).

\section{Notes and references}

1 K. K. Laali and K. Kenneth, Synthesis, 2003, 11, 1752.

2 P. L. Verma and S. P. Gejji, J. Mol. Graphics Modell., 2018, 85, 304-315.

3 K. J. Stevenson, J. Am. Chem. Soc., 2005, 127, 11878.

4 S. Letaief and C. Detellier, J. Mater. Chem., 2007, 17, 14761484.

5 F. Guo, S. Zhang, J. Wang, B. Teng, T. Zhang and M. Fan, Curr. Org. Chem., 2015, 19, 455-468.

6 Z. S. Qureshi, K. M. Deshmukh and B. M. Bhanage, Clean Technol. Environ. Policy, 2013, 16(8), 1487-1513.

7 H. T. Xu, C. H. Zhang, G. Chen, R. P. Shen and A. G. Ying, Chin. J. Chem., 2016, 36, 2353.

8 C. Yue, D. Fang, L. Liu and T. F. Yi, J. Mol. Liq., 2011, 163, 99121.

9 A. S. Khan, Z. Man, A. Arvina, M. A. Bustam, A. Nasrullah and Z. Ullah, J. Mol. Liq., 2017, 227, 98-105.

10 M. G. Montalbán, G. Víllora and P. Licence, Data in Brief, 2018, 19, 769-788.

11 T. Payagala, J. Huang, Z. S. Breitbach, P. S. Sharma and D. W. Armstrong, Chem. Mater., 2007, 19, 5848-5850.

12 Z. Zeng, B. S. Phillips, J. C. Xiao and J. M. Shreeve, Chem. Mater., 2008, 20, 2719-2726.

13 S. B. Aher and P. R. Bhagat, Res. Chem. Intermed., 2016, 42, 5587-5596.

14 R. Kore and R. Srivastava, J. Mol. Catal. A: Chem., 2003, 345, 117-126.

15 U. Domańska, E. V. Lukoshko and M. Królikowski, Chem. Eng. J., 2012, 183, 261-270.

16 V. Misuk, D. Breuch and H. Löwe, Chem. Eng. J., 2011, 173, 536-540.

17 S. A. Shamsi and N. D. Danielson, J. Sep. Sci., 2007, 30, 17291750.

18 A. M. Da Costa Lopes, K. G. João, A. R. C. Morais, E. BogelŁukasik and R. Bogel-Łukasik, Sustainable Chem. Processes, 2013, 1, 3.

19 A. P. Dadi, C. A. Schall and S. Varanasi, Appl. Biochem. Biotechnol., 2007, 137-140, 407-421.

20 F. L. Wang, S. Li, Y. X. Sun, H. Y. Han, B. X. Zhang and B. Z. Hu, RSC Adv., 2017, 7, 47990-47998.

21 J. P. Hallett and T. Welton, Chem. Rev., 2011, 111, 3508-3576.

22 S. H. Lee, T. V. Doherty, R. J. Linhardt and J. S. Dordick, Biotechnol. Bioeng., 2009, 102, 1368-1376.

23 H. T. Tan and K. T. Lee, Chem. Eng. J., 2012, 183, 448-458. 24 Z. C. Zhang, Adv. Catal., 2006, 49, 153-237.

25 H. Zhao, Chem. Eng. Commun., 2006, 193, 1660-1677.
26 N. I. Haykir, E. Bahcegul, N. Bicak and U. Bakir, Ind. Crops Prod., 2013, 41, 430-436.

27 Y. X. Sun, Y. Y. Wang, B. B. Shen, B. X. Zhang and X. M. Hu, R. Soc. Open Sci., 2018, 5, 181230.

28 Y. Dong, J. Holm, J. Karkkainen, J. Nowicki and U. Lassi, Biomass Bioenergy, 2014, 70, 461-467.

29 A. S. Amarasekara and P. Shanbhag, BioEnergy Res., 2012, 6, 719-724.

30 Y. X. An, M. H. Zong, H. Wu and N. Li, Bioresour. Technol., 2015, 192, 165-171.

31 L. Bai, X. L. Wang, Y. Nie, H. F. Dong and X. P. Zhang, Sci. China Chem., 2013, 56, 1811-1816.

32 A. H. Jadhav and H. Kim, Chem. Eng. J., 2012, 200-202, 264274.

33 M. Talebi, R. A. Patil and D. W. Armstrong, J. Mol. Liq., 2018, 256, 247-255.

34 J. F. Vélez, L. V. Álvarez, C. del Río, B. Herradón, E. Mann and E. Morales, Electrochim. Acta, 2017, 241, 517-525.

35 H. Zhang, M. Li and B. Yang, J. Phys. Chem. C, 2018, 122, 2467-2474.

36 B. S. Wang, L. Qin, T. C. Mu, Z. M. Xue and G. H. Gao, Chem. Rev., 2017, 10, 7113-7313.

37 J. C. Chang, W. Y. Ho, I. W. Sun, Y. L. Tung, M. C. Tsui, T. Y. Wu and S. S. Liang, Tetrahedron, 2010, 66, 6150-6155.

38 Z. M. Xue, L. Qin, J. Y. Jiang, T. C. Mu and G. H. Gao, Phys. Chem. Chem. Phys., 2018, 20, 8382-8402.

39 A. Chinnappan and H. Kim, Chem. Eng. J., 2012, 187, 283288.

40 Y. S. Ding, M. Zha, J. Zhang and S. S. Wang, Colloids Surf., A, 2007, 298, 201-205.

41 Y. Chen, Y. Y. Cao, X. F. Sun and T. C. Mu, J. Mol. Liq., 2014, 190, 151-158.

42 Y. Y. Cao, Y. Chen, X. F. Sun, Z. M. Zhang and T. C. Mu, Phys. Chem. Chem. Phys., 2012, 14, 12252-12262.

43 A. Hernoux-Villière, J. M. Lévêque, J. Kärkkäinen, N. Papaiconomou, M. Lajunen and U. Lassi, Catal. Today, 2014, 223, 11-17.

44 K. R. Seddon, A. Stark, M. J. Torres and T. María-José, Pure Appl. Chem., 2000, 72, 2275-2287.

45 C. Z. Li, Q. Wang and Z. B. K. Zhao, Green Chem., 2008, 2, 177-182.

46 H. H. Ma, B. X. Zhang, P. Zhang, S. Li, Y. F. Gao and X. M. Hu, Fuel Process. Technol., 2016, 148, 138-145.

47 P. Zhang, S. J. Dong, H. H. Ma, B. X. Zhang, Y. F. Wang and X. M. Hu, Ind. Crops Prod., 2015, 76, 688-696.

48 J. L. Anderson, R. Ding, A. Ellern and D. W. Armstrong, J. Am. Chem. Soc., 2005, 127, 593-604.

49 M. Moniruzzaman and T. Ono, Bioresour. Technol., 2013, 127, 132-137.

50 J. Salgado, M. Villanueva, J. J. Parajó and J. Fernández, J. Chem. Thermodyn., 2013, 65, 184-190.

51 G. Yu, S. Yan, F. Zhou, X. Liu, W. Liu and Y. Liang, Tribol. Lett., 2006, 25, 197-205. 